\title{
Preclinical Studies and Clinical Prospects of Wharton's Jelly-Derived MSC for Treatment of Acute Radiation Syndrome
}

\author{
Mayuri Bandekar $^{1,2} \cdot$ Dharmendra K. Maurya ${ }^{1,3} \cdot$ Deepak Sharma ${ }^{1,3} \cdot$ Santosh K. Sandur ${ }^{1,3}$ \\ Accepted: 30 March 2021 / Published online: 28 April 2021 \\ (C) The Author(s), under exclusive licence to Springer Nature Switzerland AG 2021
}

\begin{abstract}
Purpose of Review Wharton's jelly-derived mesenchymal stem cells (WJ-MSCs) have received widespread attention from researchers owing to the remarkable benefits offered by these cells over other stem cells. The primitive nature of WJ-MSCs, ease of isolation, differentiation ability, and immuno-modulatory nature make these cells superior to bone marrow MSCs and ideal to treat various human ailments. This review explores ability of WJ-MSCs to mitigate acute radiation syndrome caused by planned or unplanned radiation exposure.

Recent Findings Recent reports suggest that WJ-MSCs home to damaged tissues in irradiated host and mitigate radiation induced damage to radiosensitive tissues such as hematopoietic and gastrointestinal systems. WJ-MSCs and conditioned media were found to protect mice from radiation induced mortality and also prevent radiation dermatitis. Local irradiation-induced lung toxicity in mice was significantly reduced by CXCR4 over-expressing WJ-MSCs.

Summary Emerging evidences support safety and effectiveness of WJ-MSCs for treatment of acute radiation syndrome and lung injury after planned or accidental exposure. Additionally, conditioned media collected after culturing WJ-MSCs can also be used for mitigation of radiation dermatitis. Clinical translation of these findings would be possible after careful evaluation of resilience, effectiveness, and molecular mechanism of action of xenogeneic WJ-MSCs in non-human primates.
\end{abstract}

Keywords Wharton's jelly mesenchymal stem cells $\cdot$ Conditioned-media $\cdot$ Radiation dermatitis $\cdot$ G-CSF $\cdot$ Acute radiation syndrome $\cdot$ Nrf-2

\section{Introduction}

Stem cells are body's raw material or silent reserves. Unlike other specialized cells in the body such as myocytes, leukocytes, osteocytes, erythrocytes, and neurons, stem cells do not perform significant physiological functions but contribute towards homeostasis, regeneration, and repair of tissues by self-

This article is part of the Topical Collection on Radiation Biology

Dharmendra K. Maurya

dkmaurya@barc.gov.in

Santosh K. Sandur

sskumar@barc.gov.in

1 Radiation Biology \& Health Sciences Division, Bio-Science Group, Bhabha Atomic Research Centre, Trombay, Mumbai 400085, India

2 University of Mumbai, Kalina, Mumbai 400098, India

3 Homi Bhabha National Institute, Anushaktinagar, Mumbai 400094, India renewal and differentiation in to specialized cells. The fertilized egg is source of embryonic stem cells which enable organogenesis in the embryo and growth of fetus in to a fullfledged organism. The adult stem cells also help in growth of cell mass and renewal of tissues such as muscles, bones, epidermis, and blood during post-partum life and aging [1]. Recent advances in stem cell research and induced pluripotent stem cells (iPSCs) have allowed researchers to manipulate stem cells according to the medical application. The stem cells have extensive self-renewal and differentiation potential and maintain long-term stem-like state and are therefore useful in regenerative medicine [2]. Under homeostatic conditions, the stem cells maintain their numbers by symmetric division where both daughter cells remain as stem cell. They can also differentiate into more specialized type of cell via asymmetric division. The potency or stemness is a dynamic intrinsic quality of stem cells related to their varying ability to divide and self-perpetuate and respond to environmental cues by maintaining quiescence or undergoing cell division for production of differentiated cells. The potency of stem cells underlies 
their hierarchical classification as either totipotent [3], pluripotent [4], multi-potent [5], oligopotent [6], or unipotent [7]. The classification of stem cells is also based on their time of appearance during embryonic/fetal development, site of formation or tissue location in the adult body, and method of derivation in vitro [8].

\section{Types of Stem Cells}

Embryonic Stem Cells Early embryonic development from fertilized egg (zygote) involves rapid cell division resulting in formation of blastocyst within 3 to 5 days [9-11]. The inner cell mass of blastocyst contains pluripotent embryonic stem (ES) cells which can differentiate in to all types of cells present in an adult organism. The ES cells offer a potential resource for in vitro tissue-engineering and regenerative medicine [12]. ES cells are precious because they provide a renewable model for testing drugs and other therapies as well as for understanding normal development and disease. However, the research on ES cells is often cautioned or marred by ethical limitations due to their embryonic origin [13].

Adult Stem Cells or Tissue-Specific Stem Cells The undifferentiated, slow/non-dividing (quiescent) cells found in various somatic tissues in an organism (after embryonic development) are referred to as adult stem cells or tissue-specific stem cells $[8,14]$. The tissue specific stem cells are either oligopotent or multi-potent and [15] recent studies have demonstrated longterm self-renewal and directed differentiation potential of these cells into other types of cells from different germ layers [8]. Stem cells have been identified, isolated, and characterized from adipose tissue, skin, dental pulp, liver, brain, bone marrow, blood, blood vessels, and skeletal muscles in adult mice and humans. Adult stem cells actively maintain quiescence unless they receive specific cues from damaged tissue following disease or injury $[16,17]$. The specific factors required for in vitro maintenance of some adult stem cells have been identified and the therapeutic potential of in vitro expanded stem cells has been demonstrated in regenerative medicine and cancer therapy $[13,18,19]$.

Mesenchymal Stem Cells Mesenchymal stem cells (MSCs) are mainly present in the connective tissue or stroma in the bone marrow. A limited number of MSCs are also present in other organs including peripheral blood, adipose tissue, umbilical cord, cord blood, fallopian tube, liver, skin, dental pulp, and lungs [20]. In general, MSCs are multi-potent and they [21, 22] exhibit potential of tri-lineage differentiation into cells of mesenchymal origin which include osteoblasts or bone cells, chondrocytes or cartilage cells, and adipocytes (fat cells). They are used as clinically approved agents for treatment of various cancers and also as adjuvant therapy to support other treatment modalities [23, 24].

Induced Pluripotent Stem Cells About 15 years ago, Yamanaka was first to identify the factors required to reprogram adult somatic cells and produce induced pluripotent stem cells in vitro [25]. The first iPSCs were created in the laboratory from somatic cells by epigenetic reprogramming to lose tissue-specific features and express embryonic stem cellspecific genes resulting in gain of pluripotency [26, 27]. Since iPSCs possess same properties like ES cells and therefore offer a distinct advantage in terms of ethical concerns and procedural issues related to isolation of ES cells from embryo destruction, iPSCs have diverse application in drug development, transplantation medicine, and in the production of new disease models [28].

Wharton's Jelly-Mesenchymal Stem Cells Human umbilical cord is a unique source of MSCs and it has several advantages over other sources [29]. Umbilical cord Wharton's jelly appears to be cost-effective, productive, and abundant source [30] of MSCs for stem cell isolation. Wharton's jellyderived MSCs (WJ-MSCs) can be isolated in large numbers and maintained in tissue culture with no donor site morbidity, have a high proliferation rate, and maintain stemness for many passages. WJ-MSCs are multi-potent, immunosuppressive, non-tumorigenic, and well tolerated in allogeneic transplantation [31-34] as compared to MSCs derived from other sources $[35,36]$. The WJ-MSCs have a typical spindle-shape [37] and these cells fulfill three criteria set by the International Society for Cell and Gene Therapy (ISCT) guidelines to be called as stem cells [38]. WJ-MSCs have property of plastic adherence, are capable of tri-lineage differentiation into adipocytes, chondrocytes, and osteocytes, and they express stem cellspecific surface markers [39॰]. Many researchers have reported that they may be transplanted in to an allogeneic host to repair and regenerate different organs and tissues including the skin, heart, fat, cartilage, bone, cartilage, pancreas, neural, and vascular/endothelial constituents [40-45]. Experiments involving xenogeneic transplantation of human WJ-MSCderived tissues into diseased animal models have shown successful engraftment and improved organ function in vivo [31, 41•]. Functional regeneration of the lung [46], kidney [47], and liver [48] tissues using human WJ-MSCs has been shown to be associated with reduced fibrosis and improved growth of functional parenchyma and normal stroma. Many investigators have employed MSCs from bone marrow before MSCs from any other sources to treat various health conditions but BM-MSCs have been shown to have certain limitations such as HLA mapping, painful process of extraction, low yield of stem cells from bone marrow, and induction of liver fibrosis. WJ-MSCs may also promote skin regeneration by differentiation in to different types of epithelial cells found in the sweat 
glands [49]. The WJ-MSCs produce copious amounts of tissue growth promoting factors like vascular endothelial growth factor (VEGF), platelet-derived growth factor (PDGF), transforming growth factor beta (TGF- $\beta$ ), interleukin (IL)-6, insulin-like growth factor-I, and IL-8[30, 50]. Thus, easy availability of source tissue, simple method of isolation from Wharton's jelly (WJ) tissue, and their ability to repair a variety of damaged tissues in allogeneic hosts merit the use of WJMSCs in regenerative medicine [36].

Clinical Trials with WJ-MSCs The therapeutic application of WJ-MSCs for a variety of disease conditions is facilitated by their immune-privileged status. WJ-MSCs express low levels of MHC class I, MHC class II, and the co-stimulatory molecules CD40, CD80, and CD86 on their surface. They have also been shown to secrete immunosuppressive molecules such as PGE2, IDO, and HLA-G [51]. Advantage offered by WJ-MSCs is that WJ-MSCs do not express MHC class II molecules which makes these cells ideal candidate since donor matching will not be required which is a limitation of using bone marrow MSCs. Furthermore, there are no reports on clinical cases of malignant transformation of WJ-MSCs till date. Since WJ-MSCs tend to recognize and lodge at the damaged tissue site in the host, they can be transplanted via intravenous infusion or by direct injection in to the injured tissues/ organs. Owing to their potent immune-suppressive property, WJ-MSCs have become an area of extensive interest for various clinical trials in diseases involving undesired lymphocyte activation, e.g., graft-versus-host disease (GvHD), multiple sclerosis, organ transplantation, and systemic lupus erythematosus (SLE). WJ-MSCs have also been evaluated for repair and regeneration of damaged tissues in clinical trials involving human patients. The clinical trials on use of WJ-MSCs are listed in Table 1 [52]. These trials will establish the safety, tolerability, in vivo persistence, side effects, and dose of WJMSC therapy in humans. Since clinical trials in Acute Radiation Syndromes (ARS) patients cannot be routinely conducted, the outcome of ongoing trials in other disease conditions will be useful for making informed decisions about repurposing of the WJ-MSCs as therapeutics for ARS.

\section{Acute Radiation Syndrome}

Acute radiation syndrome (or sickness) encompasses a group of tissue-specific morbidities that occur in a dose-dependent manner after exposure of whole body or major parts of the body to a high dose of low LET radiations like gamma-rays and X-rays or high doses of intermediate to high LET radiations like charged particles and neutrons. The symptoms of ARS are seen after radiation exposure to $>0.5$ Gy dose of radiation delivered at a high-dose rate. The severity and time course of clinical symptoms depend upon overall body volume irradiated, the absorbed dose of ionizing radiation, the dose rate, the tissues and organs exposed, and the particle type [53-60]. Table 2 describes dose-dependent occurrence of syndromes along with clinical symptoms and also modalities for medical management. These syndromes are not mutually exclusive and exposed individuals show symptoms in multiple organ systems/tissues in a dose-dependent manner.

\section{Cellular Therapy for ARS}

The cells with higher proliferation potential like hematopoietic stem cells (HSCs) and intestinal stem cells (ISCs) are primary targets for IR-induced damage. Therefore, stem cell transplantation is a feasible therapeutic modality for treatment of radiation toxicity [39•,63]. There is special interest in stem cell therapy for ARS owing to their properties like regeneration potential, self-renewal, low antigenicity, multi-lineage differentiation, ability to home to injured site and repair the damage, and capacity to secrete modulators of inflammation. As compared to conventional drugs, scaling up of any cellular therapy for treatment of IR-exposed individuals is indeed challenging and thorough research is required to employ cellular therapy for prevention of ARS. [64].

Bone Marrow Stromal Cells Researchers from all over the world have carried out extensive preclinical studies to evaluate therapeutic efficacy of mesenchymal stem cells derived from adult tissues like bone marrow for treatment of radiation injury. Saha et al. reported that a mixture of stromal cells including endothelial, mesenchymal, and macrophage cells could be derived from the donor bone marrow in vitro. The donor stromal cells were transplanted into irradiated mice within 1-3 days after exposure to 10.4 Gy dose of whole body irradiation or $>16$ Gy dose of local irradiation of the gut. The donor cells mitigated intestinal injury via prostaglandin E2dependent suppression of inflammation and regeneration of intestinal crypt [65]. In another study, Semont et al. used xenogeneic hMSCs to treat ARS in mice after exposure to 10.5 Gy dose of WBI. hMSCs homed to the site of injury in mouse intestine and restored structural and functional integrity of small intestine by increasing proliferation and reducing cell death in crypt epithelial cells [66]. Furthermore, in a mouse model of 9 Gy whole body irradiation-induced multi-organ toxicity (hematopoietic, gastro-intestinal, and lung damage), transplantation of genetically modified syngeneic MSCs to produce extracellular SOD was found to reduce mortality related to toxicity in the hematopoietic, gut, and lung tissues [67]. Hu et al. showed that MSC treatment rescued mice from radiation-induced mortality by protecting hematopoietic cells from undergoing apoptosis, enhanced cell-cycle progression leading to recovery of WBC, platelets, and hemoglobin levels [68]. The importance of anti-inflammatory action of MSCs 
Table 1 Clinical trials on Wharton's jelly mesenchymal stem cells (clinicaltrials.gov)

\begin{tabular}{|c|c|c|c|}
\hline $\begin{array}{l}\text { Sr. } \\
\text { No. }\end{array}$ & Study title & Conditions & Status \\
\hline 1 & Use of Wharton jelly in diabetic nephropathy & Diabetic nephropathies & Not yet recruiting \\
\hline 2 & Efficacy of Wharton jelly in erectile dysfunction & Erectile dysfunction associated with type 2 diabetes mellitus & Completed \\
\hline 3 & Safety of Wharton jelly in erectile dysfunction & Erectile dysfunction associated with type 2 diabetes mellitus & Completed \\
\hline 4 & $\begin{array}{l}\text { Treatment of COVID-19 patients using Wharton's } \\
\text { jelly-mesenchymal stem cells }\end{array}$ & Use of stem cells for COVID-19 treatment & Recruiting \\
\hline 5 & Use of mesenchymal stem cells in inflammatory bowel disease & Inflammatory bowel diseases & $\begin{array}{l}\text { Active, not } \\
\text { recruiting }\end{array}$ \\
\hline 6 & $\begin{array}{l}\text { Intrathecal administration of expanded Wharton's jelly } \\
\text { mesenchymal stem cells in chronic traumatic spinal cord injury }\end{array}$ & Spinal cord injury, chronic & Completed \\
\hline 7 & $\begin{array}{l}\text { Evaluation of umbilical cord-derived Wharton's jelly stem cells for } \\
\text { the treatment of acute graft versus host disease }\end{array}$ & Acute graft versus host disease & $\begin{array}{l}\text { Active, not } \\
\text { recruiting }\end{array}$ \\
\hline 8 & $\begin{array}{l}\text { Use of Wharton jelly-derived mesenchymal stem cells for knee } \\
\text { osteoarthrosis }\end{array}$ & Knee osteoarthrosis & Recruiting \\
\hline 9 & $\begin{array}{l}\text { Management of retinitis pigmentosa by Wharton's jelly-derived } \\
\text { Mesenchymal Stem Cells }\end{array}$ & $\begin{array}{l}\text { - Retinitis pigmentosa } \\
\text { - Inherited retinal dystrophy }\end{array}$ & Completed \\
\hline 10 & $\begin{array}{l}\text { Safety and efficacy of intravenous Wharton's jelly-derived } \\
\text { mesenchymal stem cells in acute respiratory distress syndrome } \\
\text { due to COVID-19 }\end{array}$ & Acute respiratory distress syndrome & Not yet recruiting \\
\hline 11 & Wharton's jelly-derived mesenchymal stem cells in osteoarthritis & $\begin{array}{l}\text { - Osteoarthritis } \\
\text { - Hip osteoarthritis } \\
\text { - Knee osteoarthritis } \\
\text { - Glenohumeral osteoarthritis }\end{array}$ & Recruiting \\
\hline 12 & $\begin{array}{l}\text { Intracoronary human Wharton's jelly-derived mesenchymal stem } \\
\text { cells (WJ-MSCs) transfer in patients with acute myocardial } \\
\text { infarction (AMI) }\end{array}$ & ST-elevation myocardial infarction & Completed \\
\hline 13 & $\begin{array}{l}\text { Therapeutic potential of stem cell conditioned medium on chronic } \\
\text { ulcer wounds }\end{array}$ & Chronic ulcer & Not yet recruiting \\
\hline 14 & $\begin{array}{l}\text { Effect of implanting allogenic cytokines derived from human } \\
\text { amniotic membrane (HAM) and mesenchymal stem cells } \\
\text { derived from human Umbilical cord Wharton's jelly } \\
\text { (HUMCWJ) on pain and functioning of knee osteoarthritis }\end{array}$ & $\begin{array}{l}\text { - Knee osteoarthritis } \\
\text { - Knee pain chronic } \\
\text { - Joint disease } \\
\text { - Arthritis } \\
\text { - Osteo arthritis knee } \\
\text { - Musculoskeletal disease }\end{array}$ & Completed \\
\hline 15 & $\begin{array}{l}\text { Intracoronary or intravenous infusion human Wharton's } \\
\text { jelly-derived mesenchymal stem cells in patients with ischemic } \\
\text { cardiomyopathy }\end{array}$ & Ischemic cardiomyopathy & Not yet recruiting \\
\hline 16 & Therapeutic treatment of amyotrophic lateral sclerosis & Amyotrophic lateral sclerosis & Unknown \\
\hline 17 & $\begin{array}{l}\text { Pericardial matrix with mesenchymal stem cells for the treatment of } \\
\text { patients with infarcted myocardial tissue }\end{array}$ & Myocardial infarction & Recruiting \\
\hline 18 & $\begin{array}{l}\text { Cardiovascular clinical project to evaluate the regenerative capacity } \\
\text { of cardiocell in patients with acute myocardial infarction (AMI) }\end{array}$ & Myocardial infarction & Recruiting \\
\hline 19 & $\begin{array}{l}\text { Randomized study of coronary revascularization surgery with } \\
\text { injection of WJ-MSCs and placement of an epicardial } \\
\text { extracellular matrix }\end{array}$ & $\begin{array}{l}\text { - Cardiovascular diseases } \\
\text { - Heart failure } \\
\text { - Coronary artery disease } \\
\text { - Mesenchymal stem cell transplantation } \\
\text { - Regenerative medicine }\end{array}$ & Not yet recruiting \\
\hline 20 & A research study looking at specific tissue of the umbilical cord & Varices of umbilical cord & Completed \\
\hline 21 & $\begin{array}{l}\text { Efficacy and safety evaluation of mesenchymal stem cells for the } \\
\text { treatment of patients with respiratory distress due to COVID-19 }\end{array}$ & $\begin{array}{l}- \text { COVID-19 } \\
\text { - SARS-CoV } 2 \\
\text { - Adult respiratory distress syndrome }\end{array}$ & Recruiting \\
\hline 22 & $\begin{array}{l}\text { Treatment of spinal cord injuries with (AutoBM-MSCs) versus } \\
\text { (WJ-MSCs). }\end{array}$ & Spinal cord injuries & Recruiting \\
\hline 23 & $\begin{array}{l}\text { Cell therapy using umbilical cord-derived mesenchymal stromal } \\
\text { cells in SARS-CoV-2-related ARDS }\end{array}$ & $\begin{array}{l}\text { - Severe acute respiratory syndrome coronavirus } 2 \\
\text { - Severe acute respiratory distress syndrome }\end{array}$ & Recruiting \\
\hline 24 & $\begin{array}{l}\text { Randomized clinical trial to evaluate the regenerative capacity of } \\
\text { cardiocell in patients with chronic ischaemic heart failure } \\
\text { (CIHF) }\end{array}$ & Heart failure & Recruiting \\
\hline 25 & $\begin{array}{l}\text { Cardiovascular clinical project to evaluate the regenerative capacity } \\
\text { of cardiocell in patients with no-option critical limb ischemia } \\
\text { (N-O CLI) }\end{array}$ & Critical limb ischemia & Recruiting \\
\hline 26 & Role of stem cells in improving implantation rates in ICSI patients & $\begin{array}{l}\text { Assess the efficacy of differentiated and undifferentiated stem } \\
\text { cell therapy in improving endometrial receptivity. }\end{array}$ & Unknown \\
\hline 27 & $\begin{array}{l}\text { Wharton's jelly-derived mesenchymal stromal cell repeated } \\
\text { treatment of adult patients diagnosed with type I diabetes }\end{array}$ & Type 1 diabetes & Recruiting \\
\hline
\end{tabular}

has also been highlighted in radioprotection, detoxification, and hematopoietic rescue by Lange et al. [69]. Yang et al. have shown that infusion of primary or immortalized cloned marrow-derived MSCs significantly improved hematopoietic recovery and prevented mortality of mice exposed to $7.0 \mathrm{~Gy}$ dose of ionizing radiation [70]. These reports highlight the 
Table 2 Dose-wise distribution of acute radiation syndromes [61, 62]

\begin{tabular}{|c|c|c|c|}
\hline $\begin{array}{l}\text { Dose } \\
\text { (Gy) }\end{array}$ & $\begin{array}{l}\text { Radiation syndrome } \\
\text { or sickness }\end{array}$ & Indications \& possible clinical outcomes & Medical management \\
\hline $1-2$ & $\begin{array}{l}\text { Nausea, vomiting, } \\
\text { diarrhea (NVD) } \\
\text { syndrome }\end{array}$ & Nausea, vomiting, diarrhea, anorexia, giddiness, and loss of appetite & $\begin{array}{l}\text { Symptomatic treatment, antacid, sucralfate, } \\
\text { anti-emetics }\end{array}$ \\
\hline $0.7-6$ & $\begin{array}{l}\text { Hematopoietic } \\
\text { syndrome }\end{array}$ & $\begin{array}{l}\text { Loss of cellularity in the bone marrow, spleen, and thymus. } \\
\text { Low number of hematopoietic stem cells (HSCs), the individual may } \\
\text { die between 10-30 days without medical intervention. }\end{array}$ & $\begin{array}{l}\text { Antibiotics, cytokines, bone marrow transplant, } \\
\text { stem cell therapy }\end{array}$ \\
\hline$>6$ & $\begin{array}{l}\text { Gastrointestinal (GI) } \\
\text { syndrome }\end{array}$ & $\begin{array}{l}\text { Damage to intestinal crypt cells, less number of Lgr5+ intestinal stem } \\
\text { cells (ISCs), loss of absorption of nutrients, dehydration, loss of } \\
\text { weight, severe electrolyte imbalance, and low blood pressure. } \\
\text { Death occurs usually within 3-5 days without medical } \\
\text { intervention. }\end{array}$ & $\begin{array}{l}\text { Antibiotics, anti-emetics, replacement of fluids } \\
\text { and electrolytes, stem cell therapy, bone } \\
\text { marrow transplant }\end{array}$ \\
\hline$>50$ & $\begin{array}{l}\text { Central nervous } \\
\text { system (CNS) } \\
\text { syndrome }\end{array}$ & $\begin{array}{l}\text { Irritability, hyper excitability response, epileptic type fits, and coma. } \\
\text { Symptoms are irreversible. Death usually occurs within } 48 \mathrm{~h} \text {. }\end{array}$ & No treatment available \\
\hline
\end{tabular}

tendency of marrow-derived MSCs in homing to the site of radiation injury and also their ability to repair and regenerate the host tissues in the bone marrow, gut, and lungs via suppression of inflammation and secretion of growth factors.

Blood as a Source of Mobilized Progenitor Cells As compared to other mesenchymal tissues, peripheral blood contains very small number of stem cells. However, several reports have demonstrated that stem and progenitor cells can be mobilized to and harvested from donor blood for therapeutic radioprotection in vivo. Alpha-tocopherol succinate (TS) has been shown to mobilize progenitor cells from bone marrow into blood in a G-CSF-dependent manner [71]. Transfusion of the donor blood or HSC enriched blood cells from TS-treated mice rescued the recipient mice from acute radiation-induced mortality. The authors have not transplanted HSCs into irradiated mice, indicating that the protection observed may be due to HSCs mobilized in blood due to treatment with gamma-tocotrienol (GT3) [72]. Similarly, GT3 has also been used to mobilize the progenitor cells in donor blood circulation. The mobilized progenitor cells significantly reduced radiation-induced mortality in CD2F1 mice. Furthermore, finding multiple human leukocyte antigen (HLA)-matched donors for transplantations during massexposure situations would be extremely difficult; hence, this strategy can be employed to treat individuals who are at high risk of exposure to acute, high doses of ionizing radiation (e.g., military personnel, first responders) [64, 73].

Cord Blood Stem Cells The human umbilical cord blood (HUCB) contains copious number of hematopoietic stem cells and MSCs and its transfusions were first conducted in 1914 in New York City [74]. In a recent report, hUCB-MSC treatment significantly protected mice against radiation-induced hematopoietic syndrome. Transfusion of xenogeneic HUCB-MSC to BALB/c mice after 7 Gy WBI resulted in faster recovery of blood leukocytes. The radioprotective efficacy of HUCB was better than G-CSF treatment and it was associated with increased concentration of TGF- $\beta 1$ and decreased concentration of Flt3L in plasma [75]. Azzam et al. showed that transplantation of hUCB nucleated cells which are source of HSCs and an antibiotic (Levaquin) in lethally irradiated mice leads to recovery from both bone marrow and gastrointestinal syndromes [76].

Myeloid Progenitor Cells Exposure to radiation can cause severe suppression of the immune system via depletion of leukocytes and progenitor cells. Transplantation of allogenic hematopoietic stem and progenitor cells is often associated with graft-versushost disease which is mediated by donor lymphocytes. Singh et al. proposed that since MPCs produce only granulocytes, erythrocytes, monocytes, and dendritic cells but not lymphocytes, they may offer therapeutic protection against lethal doses of irradiation. The pooled MPCs from allogeneic strains of mice were transplanted in to different strains of mice after exposure to lethal dose of radiation [77]. The transplantation of allogeneic MPCs to mice up to 7 days after exposure to lethal dose of radiation ( 9 to 15 Gy gamma and X-rays) offered significant survival advantage in a dose-dependent manner. Radioprotective action of MPCs was associated with regeneration of functional intestinal lining, prevention of bacterial leakage from gut, and recovery of hematopoietic system indicating their possible therapeutic use as a bridging therapy for radiation-induced hematopoietic and GI syndromes [77].

\section{WJ-MSCs for ARS}

Although allogeneic hematopoietic stem cell transplantation can rescue the leukemia patients from chemo/radiotherapy induced myeloablation, it is often associated with graftversus-host disease (GvHD) in up to $40 \%$ of the recipients [78]. Mesenchymal stem cells offer a promising treatment modality for management of GvHD, systemic lupus 
erythematosus (SLE), myocardial infarction (MI), amyotrophic lateral sclerosis (ALS), osteoarthritis (OA), spinal cord injury (SCI), diabetes mellitus (DM), multiple sclerosis (MS), and other diseases [36]. Similarly, human ES cells and iPSC are pluripotent and offer many advantages [79, 80]. Human bone marrow-derived MSCs (BM-MSCs) have many beneficial properties which make them ideal for research and therapy. However, their isolation involves invasive and painful method and poses a risk of infection and donor site morbidity. Other practical limitations related to human bone marrowderived MSCs include their low frequency $(0.001-0.01 \%)$ and aging-dependent deterioration of stemness [34, 81•]. Since the frequency of BM-MSCs is very low in bone marrow aspirates, they must be extensively multiplied in vitro for any therapeutic application. In vitro expansion is associated with increased risk of unwanted epigenetic modifications [82, 83]. The MSCs isolated from umbilical cord blood (UCB) offer several advantages including better grafting and regenerative potential. However, their limited numbers as compared to WJ-MSCs and slow cell division cycle can hamper their practical utility in regenerative medicine [84]. To overcome these key drawbacks, the umbilical cord, a biomedical waste, has gained the attention of many investigators as an alternative source of MSCs.

The MSCs are interspersed in the walls (Wharton's jelly, WJ) of the umbilical cord and their high abundance, ease of isolation, resilience, and amenability to in vitro expansion and manipulation make them an attractive candidate for use in regenerative medicine and research [85 $]$. The WJ-MSCs are isolated from tissue which is normally discarded ruling out ethical issues associated with ESCs. They have higher proliferation rate and their stem cell properties are retained over many passages. They are considered to be more primitive in nature as compared to other sources of MSCs due to expression of markers related to mesenchymal as well as embryonic stem cells, potential for long-term self-renewal, and multilineage differentiation. The low immunogenicity, immunosuppressive action, and non-tumorigeneic nature makes WJMSCs suitable for allogeneic and xenogeneic transplantation in experimental models $[31,45,86 \bullet]$.

\section{Role of WJ-MSCs in Protection from ARS}

WJ-MSCs have been demonstrated to heal the symptoms of ARS in a variety of experimental systems. A recent study from our lab showed that treatment of mice with human WJ-MSCs offered significant therapeutic protection against radiation $(8.5$ Gy)-induced death (Scheme 1) [39॰]. The donor WJ-MSCs preferentially homed into radiosensitive tissues like the spleen, bone marrow, and small intestine of irradiated mice and improved recovery from radiation-induced toxicity in vivo. The therapeutic effect of WJ-MSCs was seen when transplantation was carried out up to $24 \mathrm{~h}$ WBI. During a radiological emergency event, people are exposed to a range of doses and supportive care in the form of antibiotics, analgesics is often given to these victims to prevent life-threatening and opportunistic infections. Combination of WJ-MSCs with tetracycline synergistically enhanced the survival benefit when administered $24 \mathrm{~h}$ post-irradiation. WJ-MSCs indeed protect HSCs from radiation-induced damage and these responder HSCs then proliferate and repopulate the hematopoietic system thus prevent hematopoietic ARS-related death. The contribution of secretory factors from WJ-MSCs towards radioprotection was demonstrated in terms of significant prevention of death in mice treated with conditioned media up to $24 \mathrm{~h}$ after exposure to radiation. The transplanted xenogeneic WJ-MSCs produced human cytokines and enhanced the production of mouse cytokines in the irradiated mice. Among these, WJ-MSC-derived human IL-6 and G-CSF were found to play a causal role in radioprotection. We also identified an essential role of Nrf- 2 in the host mice as well as transplanted human WJ-MSCs for the observed radioprotection. Thus, WJ-MSC-based cell therapy may offer an alternative to allogeneic bone marrow transplantation during accidental radiation exposure scenario [39•].

Cancer patients who are treated with radiotherapy in thoracic region often develop pulmonary complications like pneumonia, infections, and fibrosis. Radiation-induced lung injury (RILI) not only affects quality of life after radiotherapy but also increases the chances of death. Zhang et al. reported that overexpression of chemokine receptor CXCR4 in WJ-MSCs can increase their therapeutic potential for treatment of RILI. They showed that CXCR4-overexpressing HUMSCs were able to offer enhanced protection against RILI. These protective effects were attributed to efficient homing and retention of transplanted HUMSCs in the injured lung tissues and improved histopathological changes. In this study, thoracic region of mice was irradiated with $13 \mathrm{~Gy}$ dose of X-rays and treated with CXCR $4^{\text {high }}-$ WJ-MSCs. Radioprotection of mice was found to be associated with preferential homing of human CXCR $4{ }^{\text {high }}$-WJ-MSCs in lung tissues, reduction of radiation-induced increase in SDF-1, TGF- $\beta 1, \alpha$ SMA, and collagen I levels, and amelioration of radiationinduced decrease in expression of E-cadherin leading to moderation of RILI. These results demonstrate safety and efficacy of WJ-MSCs overexpressing CXCR4 for mitigation of RILI [87].

Radiation-induced skin injury or radiation dermatitis is another noticeable side effect seen during radiotherapy. A serious skin reaction can limit the duration and dose of radiation that can be delivered to the patient. Sun et al. reported that the culture supernatant collected from WJ-MSC could be used for the treatment of radiation dermatitis in rats in the form of hydrogels [88•]. The radiation-induced skin injury in rat model was created by exposing to localized radiation dose of $40 \mathrm{~Gy}$ in an area of $2 \times 2 \mathrm{~cm}$ for $25 \mathrm{~min}$. A total of $200 \mu \mathrm{l}$ of MSC-CMhydrogel was pipetted onto the radiation wound every 2 days for 8 weeks. The protective and regenerative action was shown to be dependent on secreted factors that increase angiogenesis, 


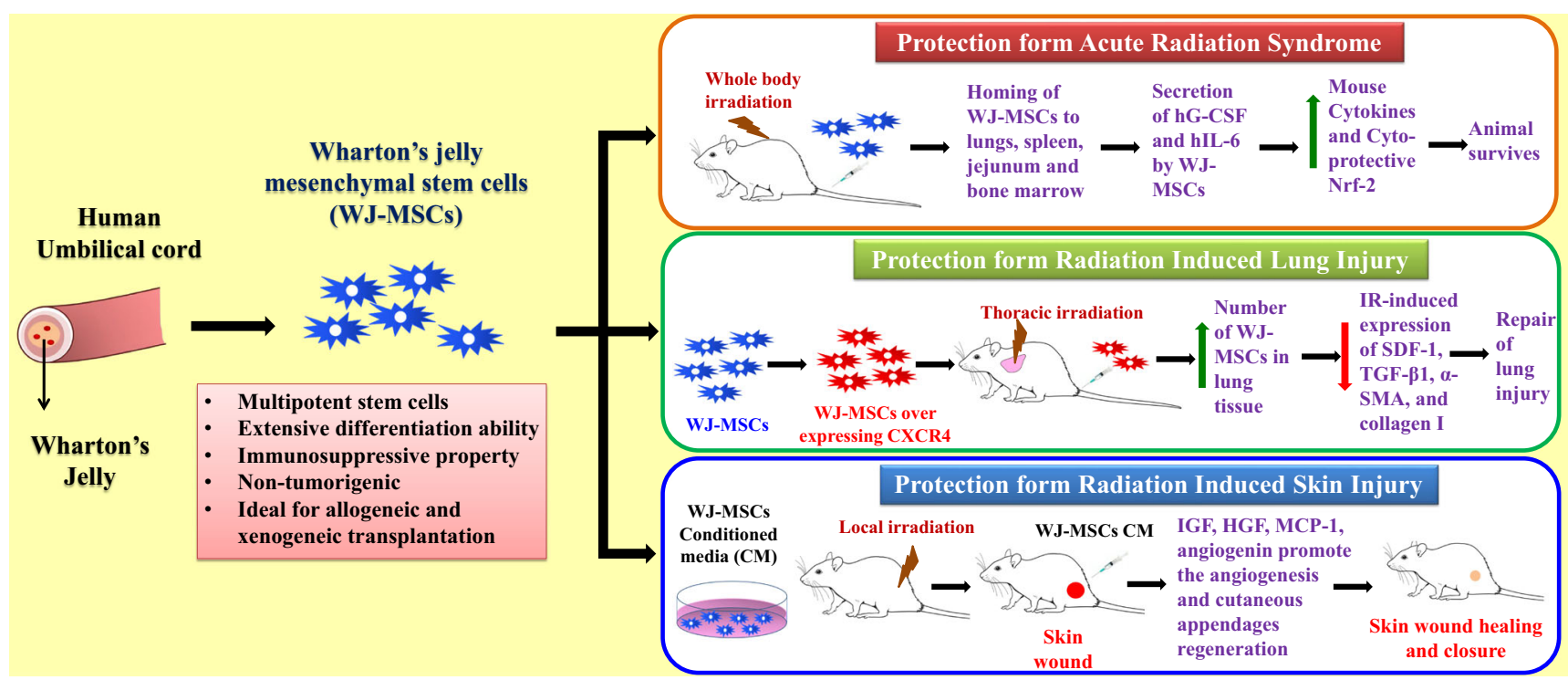

Scheme 1 Mechanism of therapeutic radioprotection by WJ-MSCs

regenerate sebaceous glands, and promote cell division in endothelial cells. The conditioned medium from WJ-MSC also accelerated scar-free wound healing quality. These findings point towards an urgent need for optimization and benchmarking of the method of isolation and preservation of conditioned media from WJ-MSCs for possible use as a therapeutic agent for treatment of radiation induced dermatitis [88•].

In order to translate the radioprotective effects of WJ-MSCs to a large-scale mass exposure scenario involving hundreds of thousands of individuals, WJ-MSCs need to be sourced from normal volunteers, expanded, and cryo-banked well in advance. These cells can then be thawed and transfused at point of care in eligible individuals. Furthermore, the WJ-MSC conditioned media which offered significant therapeutic radioprotection can be easily stored at $-80^{\circ} \mathrm{C}$ in large quantity and can also be administered to large number of individuals exposed to IR. However, extensive preclinical research is required before these approaches can be approved as a viable radiation countermeasure.

\section{Conclusions}

This review provides recent insights about the utility of WJMSCs vis-a-vis other MSCs from adult tissues for treatment of acute radiation toxicity. The ease of isolation, wide differentiation potential, and immuno-modulatory nature and trivial ethical concerns make WJ-MSCs ideal for allogeneic and xenogeneic transplantation to treat various diseases and disorders. Exposure to radiation leads to acute radiation syndromes which involve damage to hematopoietic, gastrointestinal, and neurovascular systems. WJ-MSCs protect mice from radiation-induced mortality via secretion of cyto-protective cytokines like G-CSF, IL-6, and the protection is dependent on Nrf-2 of the host. Conditioned medium of WJ-MSCs also protects mice against radiation- induced mortality and it protects rats against radiation dermatitis. CXCR4 overexpressing WJ-MSCs protect mice against radiation-induced lung injury by decreasing the expression of SDF-1, TGF- $\beta 1, \alpha$-SMA, and collagen I. These findings highlight the utility of WJ-MSCs in mitigating acute radiation syndromes. However, extensive studies need be carried out to elucidate the mechanism of action and also to further expand the window of protection beyond 24h. The optimization of dose, duration, and frequency of WJ-MSCs transplantation and preserving stemness during in vitro expansion will be important for translation of preclinical findings to successful clinical trials. Furthermore, unraveling the detailed mechanisms responsible for WJ-MSCs mediated tissue regeneration and demonstration of their safety and efficacy in non-human primates will expedite the prospects of their use in patients.

Funding The authors acknowledge the financial support from Department of Atomic Energy, Government of India.

Conflict of interests The authors declare no conflicts interests.

Human and Animal Rights and Informed Consent Not applicable.

\section{References}

Papers of particular interest, published recently, have been highlighted as:

- Of importance

1. Bacakova L, Zarubova J, Travnickova M, Musilkova J, Pajorova J, Slepicka P, et al. Stem cells: their source, potency and use in 
regenerative therapies with focus on adipose-derived stem cells - a review. Biotechnol Adv. 2018;36(4):1111-26. https://doi.org/10. 1016/j.biotechadv.2018.03.011.

2. Gabut M, Bourdelais F, Durand S. Ribosome and translational control in stem cells. Cells. 2020;9(2). https://doi.org/10.3390/ cells 9020497.

3. Weissman IL. Stem cells: units of development, units of regeneration, and units in evolution. Cell. 2000;100(1):157-68. https://doi. org/10.1016/s0092-8674(00)81692-x

4. Shamblott MJ, Axelman J, Wang S, Bugg EM, Littlefield JW, Donovan PJ, et al. Derivation of pluripotent stem cells from cultured human primordial germ cells. Proc Natl Acad Sci U S A. 1998;95(23):13726-31. https://doi.org/10.1073/pnas.95.23.13726.

5. Zuk PA, Zhu M, Ashjian P, De Ugarte DA, Huang JI, Mizuno H, et al. Human adipose tissue is a source of multipotent stem cells. Mol Biol Cell. 2002;13(12):4279-95. https://doi.org/10.1091/mbc. e02-02-0105.

6. Majo F, Rochat A, Nicolas M, Jaoude GA, Barrandon Y. Oligopotent stem cells are distributed throughout the mammalian ocular surface. Nature. 2008;456(7219):250-4. https://doi.org/10. 1038/nature07406.

7. Blanpain C, Horsley V, Fuchs E. Epithelial stem cells: turning over new leaves. Cell. 2007;128(3):445-58. https://doi.org/10.1016/j. cell.2007.01.014.

8. Rajabzadeh N, Fathi E, Farahzadi R. Stem cell-based regenerative medicine. Stem Cell Investig. 2019;6:19. https://doi.org/10.21037/ sci.2019.06.04.

9. Biswas A, Hutchins R. Embryonic stem cells. Stem Cells Dev. 2007;16(2):213-22. https://doi.org/10.1089/scd.2006.0081.

10. Kang L, Kou Z, Zhang Y, Gao S. Induced pluripotent stem cells (iPSCs)-a new era of reprogramming. J Genet Genomics. 2010;37(7):415-21. https://doi.org/10.1016/S1673-8527(09) 60060-6.

11. Kokkinaki M, Djourabtchi A, Golestaneh N. Long-term culture of human SSEA-4 positive spermatogonial stem cells (SSCs). J Stem Cell Res Ther. 2011;2(2). https://doi.org/10.4172/2157-7633.S2003.

12. Rippon HJ, Bishop AE. Embryonic stem cells. Cell Prolif. 2004;37(1):23-34. https://doi.org/10.1111/j.1365-2184.2004. 00298.x.

13. Chu DT, Nguyen TT, Tien NLB, Tran DK, Jeong JH, Anh PG, et al. Recent progress of stem cell therapy in cancer treatment: molecular mechanisms and potential applications. Cells. 2020;9(3). https://doi.org/10.3390/cells9030563.

14. Toma JG, Akhavan M, Fernandes KJ, Barnabe-Heider F, Sadikot A, Kaplan DR, et al. Isolation of multipotent adult stem cells from the dermis of mammalian skin. Nat Cell Biol. 2001;3(9):778-84. https://doi.org/10.1038/ncb0901-778.

15. Johnson TA, Singla DK. Therapeutic application of adult stem cells in the heart. Methods Mol Biol. 2017;1553:249-64. https://doi.org/ 10.1007/978-1-4939-6756-8_20.

16. Oswald J, Boxberger S, Jorgensen B, Feldmann S, Ehninger G, Bornhauser M, et al. Mesenchymal stem cells can be differentiated into endothelial cells in vitro. Stem Cells. 2004;22(3):377-84. https://doi.org/10.1634/stemcells.22-3-377.

17. Mahla RS. Stem cells applications in regenerative medicine and disease therapeutics. Int J Cell Biol. 2016;2016:6940283. https:// doi.org/10.1155/2016/6940283.

18. Mimeault M, Hauke R, Batra SK. Stem cells: a revolution in therapeutics-recent advances in stem cell biology and their therapeutic applications in regenerative medicine and cancer therapies. Clin Pharmacol Ther. 2007;82(3):252-64. https://doi.org/10.1038/ sj.clpt.6100301.

19. Rameshwar P, Moore CA, Shah NN, Smith CP. An update on the therapeutic potential of stem cells. Methods Mol Biol. 1842;2018: 3-27. https://doi.org/10.1007/978-1-4939-8697-2_1.
20. Caplan AI. Mesenchymal stem cells: time to change the name! Stem Cells Transl Med. 2017;6(6):1445-51. https://doi.org/10. 1002/sctm.17-0051.

21. Ejtehadifar M, Shamsasenjan K, Movassaghpour A, Akbarzadehlaleh P, Dehdilani N, Abbasi P, et al. The effect of hypoxia on mesenchymal stem cell biology. Adv Pharm Bull. 2015;5(2):141-9. https://doi.org/10.15171/apb.2015.021.

22. Mohammadian M, Shamsasenjan K, Lotfi Nezhad P, Talebi M, Jahedi M, Nickkhah H, et al. Mesenchymal stem cells: new aspect in cell-based regenerative therapy. Adv Pharm Bull. 2013;3(2): 433-7. https://doi.org/10.5681/apb.2013.070.

23. Christodoulou I, Goulielmaki M, Devetzi M, Panagiotidis M, Koliakos G, Zoumpourlis V. Mesenchymal stem cells in preclinical cancer cytotherapy: a systematic review. Stem Cell Res Ther. 2018;9(1):336. https://doi.org/10.1186/s13287-018-1078-8.

24. Lin W, Huang L, Li Y, Fang B, Li G, Chen L, et al. Mesenchymal stem cells and cancer: clinical challenges and opportunities. Biomed Res Int. 2019;2019:2820853. https://doi.org/10.1155/ 2019/2820853.

25. Takahashi K, Yamanaka S. Induction of pluripotent stem cells from mouse embryonic and adult fibroblast cultures by defined factors. Cell. 2006;126(4):663-76. https://doi.org/10.1016/j.cell.2006.07. 024 .

26. Ohnuki M, Takahashi K. Present and future challenges of induced pluripotent stem cells. Philos Trans R Soc Lond Ser B Biol Sci. 2015;370(1680):20140367. https://doi.org/10.1098/rstb.2014. 0367.

27. Glicksman MA. Induced pluripotent stem cells: the most versatile source for stem cell therapy. Clin Ther. 2018;40(7):1060-5. https:// doi.org/10.1016/j.clinthera.2018.06.004.

28. Yu J, Vodyanik MA, Smuga-Otto K, Antosiewicz-Bourget J, Frane JL, Tian S, et al. Induced pluripotent stem cell lines derived from human somatic cells. Science. 2007;318(5858):1917-20. https:// doi.org/10.1126/science.1151526.

29. Davies JE, Walker JT, Keating A. Concise review: Wharton's jelly: the rich, but enigmatic, source of mesenchymal stromal cells. Stem Cells Transl Med. 2017;6(7):1620-30. https://doi.org/10.1002/ sctm.16-0492.

30. Arno AI, Amini-Nik S, Blit PH, Al-Shehab M, Belo C, Herer E, et al. Human Wharton's jelly mesenchymal stem cells promote skin wound healing through paracrine signaling. Stem Cell Res Ther. 2014;5(1):28. https://doi.org/10.1186/scrt417.

31. Fong CY, Subramanian A, Biswas A, Gauthaman K, Srikanth P, Hande MP, et al. Derivation efficiency, cell proliferation, freezethaw survival, stem-cell properties and differentiation of human Wharton's jelly stem cells. Reprod BioMed Online. 2010;21(3): 391-401. https://doi.org/10.1016/j.rbmo.2010.04.010.

32. La Rocca G, Anzalone R, Corrao S, Magno F, Loria T, Lo Iacono $\mathrm{M}$, et al. Isolation and characterization of Oct-4+/HLA-G+ mesenchymal stem cells from human umbilical cord matrix: differentiation potential and detection of new markers. Histochem Cell Biol. 2009;131(2):267-82. https://doi.org/10.1007/s00418-008-0519-3.

33. Mitchell KE, Weiss ML, Mitchell BM, Martin P, Davis D, Morales L, et al. Matrix cells from Wharton's jelly form neurons and glia. Stem Cells. 2003;21(1):50-60. https://doi.org/10.1634/stemcells. 21-1-50

34. Troyer DL, Weiss ML. Wharton's jelly-derived cells are a primitive stromal cell population. Stem Cells. 2008;26(3):591-9. https://doi. org/10.1634/stemcells.2007-0439.

35. Bongso A, Fong CY. The therapeutic potential, challenges and future clinical directions of stem cells from the Wharton's jelly of the human umbilical cord. Stem Cell Rev Rep. 2013;9(2):226-40. https://doi.org/10.1007/s12015-012-9418-z.

36. Liau LL, Ruszymah BHI, Ng MH, Law JX. Characteristics and clinical applications of Wharton's jelly-derived mesenchymal 
stromal cells. Curr Res Transl Med. 2020;68(1):5-16. https://doi. org/10.1016/j.retram.2019.09.001.

37. Ranjbaran H, Abediankenari S, Mohammadi M, Jafari N, Khalilian A, Rahmani Z, et al. Wharton's jelly derived-mesenchymal stem cells: isolation and characterization. Acta Med Iran. 2018;56(1):28-33.

38. Dominici M, Le Blanc K, Mueller I, Slaper-Cortenbach I, Marini F, Krause D, et al. Minimal criteria for defining multipotent mesenchymal stromal cells. The International Society for Cellular Therapy position statement. Cytotherapy. 2006;8(4):315-7. https://doi.org/10.1080/14653240600855905.

39. Bandekar M, Maurya DK, Sharma D, Checker R, Gota V, Mishra $\mathrm{N}$, et al. Xenogeneic transplantation of human WJ-MSCs rescues mice from acute radiation syndrome via Nrf-2-dependent regeneration of damaged tissues. Am J Transplant. 2020. https://doi.org/10. 1111/ajt.15819 This study demonstrated the therapeutic radioprotective efficacy of the human Wharton's jelly MSCs, their conditioned medium and also established their use in the xenogeneic model.

40. Nekanti U, Rao VB, Bahirvani AG, Jan M, Totey S, Ta M. Longterm expansion and pluripotent marker array analysis of Wharton's jelly-derived mesenchymal stem cells. Stem Cells Dev. 2010;19(1): 117-30. https://doi.org/10.1089/scd.2009.0177.

41. Chao KC, Chao KF, Fu YS, Liu SH. Islet-like clusters derived from mesenchymal stem cells in Wharton's Jelly of the human umbilical cord for transplantation to control type 1 diabetes. PLoS One. 2008;3(1):e1451. https://doi.org/10.1371/journal.pone. 0001451 In this research paper, human umbilical cord MSCs were differentiated into mature islet-like cell clusters, which possess insulin-producing ability in vitro and in vivo.

42. Fu YS, Cheng YC, Lin MY, Cheng H, Chu PM, Chou SC, et al. Conversion of human umbilical cord mesenchymal stem cells in Wharton's jelly to dopaminergic neurons in vitro: potential therapeutic application for Parkinsonism. Stem Cells. 2006;24(1):11524. https://doi.org/10.1634/stemcells.2005-0053.

43. Hou T, Xu J, Wu X, Xie Z, Luo F, Zhang Z, et al. Umbilical cord Wharton's Jelly: a new potential cell source of mesenchymal stromal cells for bone tissue engineering. Tissue Eng Part A. 2009;15(9):2325-34. https://doi.org/10.1089/ten.tea.2008.0402.

44. Wang L, Tran I, Seshareddy K, Weiss ML, Detamore MS. A comparison of human bone marrow-derived mesenchymal stem cells and human umbilical cord-derived mesenchymal stromal cells for cartilage tissue engineering. Tissue Eng Part A. 2009;15(8):2259 66. https://doi.org/10.1089/ten.tea.2008.0393.

45. Fong CY, Chak LL, Biswas A, Tan JH, Gauthaman K, Chan WK, et al. Human Wharton's jelly stem cells have unique transcriptome profiles compared to human embryonic stem cells and other mesenchymal stem cells. Stem Cell Rev Rep. 2011;7(1):1-16. https:// doi.org/10.1007/s12015-010-9166-x.

46. Moodley Y, Atienza D, Manuelpillai U, Samuel CS, Tchongue J, Ilancheran S, et al. Human umbilical cord mesenchymal stem cells reduce fibrosis of bleomycin-induced lung injury. Am J Pathol. 2009;175(1):303-13. https://doi.org/10.2353/ajpath.2009.080629.

47. Du T, Cheng J, Zhong L, Zhao XF, Zhu J, Zhu YJ, et al. The alleviation of acute and chronic kidney injury by human Wharton's jelly-derived mesenchymal stromal cells triggered by ischemia-reperfusion injury via an endocrine mechanism. Cytotherapy. 2012;14(10):1215-27. https://doi.org/10.3109/ 14653249.2012.711471.

48. Tsai PC, Fu TW, Chen YM, Ko TL, Chen TH, Shih YH, et al. The therapeutic potential of human umbilical mesenchymal stem cells from Wharton's jelly in the treatment of rat liver fibrosis. Liver Transpl. 2009;15(5):484-95. https://doi.org/10.1002/lt.21715.

49. Xu Y, Huang S, Ma K, Fu X, Han W, Sheng Z. Promising new potential for mesenchymal stem cells derived from human umbilical cord Wharton's jelly: sweat gland cell-like differentiative capacity. J Tissue Eng Regen Med. 2012;6(8):645-54. https://doi. org/10.1002/term.468.

50. Choi M, Lee HS, Naidansaren P, Kim HK. O E, Cha JH et al. Proangiogenic features of Wharton's jelly-derived mesenchymal stromal/stem cells and their ability to form functional vessels. Int J Biochem Cell Biol. 2013;45(3):560-70. https://doi.org/10.1016/j. biocel.2012.12.001.

51. Liu S, Yuan M, Hou K, Zhang L, Zheng X, Zhao B, et al. Immune characterization of mesenchymal stem cells in human umbilical cord Wharton's jelly and derived cartilage cells. Cell Immunol. 2012;278(1-2):35-44. https://doi.org/10.1016/j.cellimm.2012.06. 010 .

52. Marino L, Castaldi MA, Rosamilio R, Ragni E, Vitolo R, Fulgione $\mathrm{C}$, et al. Mesenchymal stem cells from the Wharton's jelly of the human umbilical cord: biological properties and therapeutic potential. Int J Stem Cells. 2019;12(2):218-26. https://doi.org/10.15283/ ijsc18034.

53. Macia IGM, Lucas Calduch A, Lopez EC. Radiobiology of the acute radiation syndrome. Rep Pract Oncol Radiother. 2011;16(4):123-30. https://doi.org/10.1016/j.rpor.2011.06.001.

54. Stone HB, Coleman CN, Anscher MS, McBride WH. Effects of radiation on normal tissue: consequences and mechanisms. Lancet Oncol. 2003;4(9):529-36. https://doi.org/10.1016/s1470-2045(03) 01191-4.

55. Donnelly EH, Nemhauser JB, Smith JM, Kazzi ZN, Farfan EB, Chang AS, et al. Acute radiation syndrome: assessment and management. South Med J. 2010;103(6):541-6. https://doi.org/10. 1097/SMJ.0b013e3181ddd571.

56. Hofer M, Pospisil M, Komurkova D, Hoferova Z. Granulocyte colony-stimulating factor in the treatment of acute radiation syndrome: a concise review. Molecules. 2014;19(4):4770-8. https:// doi.org/10.3390/molecules19044770.

57. Reeves GI, Ainsworth EJ. Description of the chronic radiation syndrome in humans irradiated in the former Soviet Union. Radiat Res. 1995;142(2):242-3.

58. Nieder C, Milas L, Ang KK. Tissue tolerance to reirradiation. Semin Radiat Oncol. 2000;10(3):200-9. https://doi.org/10.1053/ srao.2000.6593.

59. Taylor CW, Nisbet A, McGale P, Darby SC. Cardiac exposures in breast cancer radiotherapy: 1950s-1990s. Int J Radiat Oncol Biol Phys. 2007;69(5):1484-95. https://doi.org/10.1016/j.ijrobp.2007. 05.034 .

60. Mothersill C, Seymour C. Radiation-induced bystander effects: past history and future directions. Radiat Res. 2001;155(6):759-67. https:// doi.org/10.1667/0033-7587(2001)155[0759:ribeph]2.0.co;2.

61. Lopez M, Martin M. Medical management of the acute radiation syndrome. Rep Pract Oncol Radiother. 2011;16(4):138-46. https:// doi.org/10.1016/j.rpor.2011.05.001.

62. Singh VK, Seed TM. A review of radiation countermeasures focusing on injury-specific medicinals and regulatory approval status: part I. Radiation sub-syndromes, animal models and FDAapproved countermeasures. Int J Radiat Biol. 2017;93(9):851-69. https://doi.org/10.1080/09553002.2017.1332438.

63. Semont A, Francois S, Mouiseddine M, Francois A, Sache A, Frick $\mathrm{J}$, et al. Mesenchymal stem cells increase self-renewal of small intestinal epithelium and accelerate structural recovery after radiation injury. Adv Exp Med Biol. 2006;585:19-30. https://doi.org/10. 1007/978-0-387-34133-0 2.

64. Singh VK, Hanlon BK, Santiago PT, Seed TM. A review of radiation countermeasures focusing on injury-specific medicinals and regulatory approval status: part III. Countermeasures under early stages of development along with 'standard of care' medicinal and procedures not requiring regulatory approval for use. Int $\mathrm{J}$ Radiat Biol. 2017;93(9):885-906. https://doi.org/10.1080/ 09553002.2017 .1332440 
65. Saha S, Bhanja P, Kabarriti R, Liu L, Alfieri AA, Guha C. Bone marrow stromal cell transplantation mitigates radiation-induced gastrointestinal syndrome in mice. PLoS One. 2011;6(9):e24072. https://doi.org/10.1371/journal.pone.0024072.

66. Semont A, Mouiseddine M, Francois A, Demarquay C, Mathieu N, Chapel A, et al. Mesenchymal stem cells improve small intestinal integrity through regulation of endogenous epithelial cell homeostasis. Cell Death Differ. 2010;17(6):952-61. https://doi.org/10. 1038/cdd.2009.187.

67. Abdel-Mageed AS, Senagore AJ, Pietryga DW, Connors RH, Giambernardi TA, Hay RV, et al. Intravenous administration of mesenchymal stem cells genetically modified with extracellular superoxide dismutase improves survival in irradiated mice. Blood. 2009;113(5):1201-3. https://doi.org/10.1182/blood-2008-07170936.

68. Hu KX, Sun QY, Guo M, Ai HS. The radiation protection and therapy effects of mesenchymal stem cells in mice with acute radiation injury. Br J Radiol. 2010;83(985):52-8. https://doi.org/10. 1259/bjr/61042310.

69. Lange C, Brunswig-Spickenheier B, Cappallo-Obermann H, Eggert K, Gehling UM, Rudolph C, et al. Radiation rescue: mesenchymal stromal cells protect from lethal irradiation. PLoS One. 2011;6(1):e14486. https://doi.org/10.1371/journal.pone.0014486.

70. Yang X, Balakrishnan I, Torok-Storb B, Pillai MM. Marrow stromal cell infusion rescues hematopoiesis in lethally irradiated mice despite rapid clearance after infusion. Adv Hematol. 2012;2012: 142530. https://doi.org/10.1155/2012/142530.

71. Singh VK, Brown DS, Kao TC. Alpha-tocopherol succinate protects mice from gamma-radiation by induction of granulocytecolony stimulating factor. Int J Radiat Biol. 2010;86(1):12-21. https://doi.org/10.3109/09553000903264515.

72. Singh VK, Brown DS, Kao TC, Seed TM. Preclinical development of a bridging therapy for radiation casualties. Exp Hematol. 2010;38(1):61-70. https://doi.org/10.1016/j.exphem.2009.10.008.

73. Singh VK, Wise SY, Fatanmi OO, Scott J, Romaine PL, Newman VL, et al. Progenitors mobilized by gamma-tocotrienol as an effective radiation countermeasure. PLoS One. 2014;9(11):e114078. https://doi.org/10.1371/journal.pone.0114078.

74. Kovalenko OA, Azzam EI, Ende N. Human umbilical-cord-blood mononucleated cells enhance the survival of lethally irradiated mice: dosage and the window of time. J Radiat Res. 2013;54(6): 1010-4. https://doi.org/10.1093/jrr/rrt062.

75. Shim S, Lee SB, Lee JG, Jang WS, Lee SJ, Park S, et al. Mitigating effects of hUCB-MSCs on the hematopoietic syndrome resulting from total body irradiation. Exp Hematol. 2013;41(4):346-53.e2. https://doi.org/10.1016/j.exphem.2013.01.002.

76. Azzam EI, Yang Z, Li M, Kim S, Kovalenko OA, Khorshidi M, et al. The effect of human cord blood therapy on the intestinal tract of lethally irradiated mice: possible use for mass casualties. Int $\mathrm{J}$ Radiat Biol. 2010;86(6):467-75. https://doi.org/10.3109/ 09553000903567987.

77. Singh VK, Christensen J, Fatanmi OO, Gille D, Ducey EJ, Wise SY, et al. Myeloid progenitors: a radiation countermeasure that is effective when initiated days after irradiation. Radiat Res. 2012;177(6):781-91. https://doi.org/10.1667/rr2894.1.

78. McGuirk JP, Smith JR, Divine CL, Zuniga M, Weiss ML. Wharton's jelly-derived mesenchymal stromal cells as a promising cellular therapeutic strategy for the management of graft-versus- host disease. Pharmaceuticals (Basel). 2015;8(2):196-220. https:// doi.org/10.3390/ph8020196.

79. Carpenter MK, Frey-Vasconcells J, Rao MS. Developing safe therapies from human pluripotent stem cells. Nat Biotechnol. 2009;27(7):606-13. https://doi.org/10.1038/nbt0709-606.

80. Luong MX, Smith KP, Stein GS. Human embryonic stem cell registries: value, challenges and opportunities. J Cell Biochem. 2008;105(3):625-32. https://doi.org/10.1002/jcb.21872.

81. Mueller SM, Glowacki J. Age-related decline in the osteogenic potential of human bone marrow cells cultured in threedimensional collagen sponges. J Cell Biochem. 2001;82(4):58390. https://doi.org/10.1002/jcb.1174.

82. Redaelli S, Bentivegna A, Foudah D, Miloso M, Redondo J, Riva $\mathrm{G}$, et al. From cytogenomic to epigenomic profiles: monitoring the biologic behavior of in vitro cultured human bone marrow mesenchymal stem cells. Stem Cell Res Ther. 2012;3(6):47. https://doi. org/10.1186/scrt138.

83. Gong W, Han Z, Zhao H, Wang Y, Wang J, Zhong J, et al. Banking human umbilical cord-derived mesenchymal stromal cells for clinical use. Cell Transplant. 2012;21(1):207-16. https://doi.org/10. 3727/096368911X586756.

84. Musina RA, Bekchanova ES, Belyavskii AV, Grinenko TS, Sukhikh GT. Umbilical cord blood mesenchymal stem cells. Bull Exp Biol Med. 2007;143(1):127-31. https://doi.org/10.1007/ s10517-007-0032-z.

85. Subramanian A, Fong CY, Biswas A, Bongso A. Comparative characterization of cells from the various compartments of the human umbilical cord shows that the Wharton's jelly compartment provides the best source of clinically utilizable mesenchymal stem cells. PLoS One. 2015;10(6):e0127992. https://doi.org/10.1371/ journal.pone.0127992 This article established a standardized process for manufacture of human umbilical cord-derived MSCs and also demonstrated the safety and efficacy of those MSCs during the clinical applications.

86. Shivakumar SB, Bharti D, Subbarao RB, Jang SJ, Park JS, Ullah I, et al. DMSO- and serum-free cryopreservation of Wharton's jelly tissue isolated from human umbilical cord. J Cell Biochem. 2016;117(10):2397-412. https://doi.org/10.1002/jcb.25563.

87. Zhang C, Zhu Y, Wang J, Hou L, Li W, An H. CXCR4overexpressing umbilical cord mesenchymal stem cells enhance protection against radiation-induced lung injury. Stem Cells Int. 2019;2019:2457082. https://doi.org/10.1155/2019/2457082 This study showed that CXCR4-overexpressing human umbilical cord MSCs enhanced the protection against radiationinduced lung injury and may be a promising strategy for mitigation of radiation induced lung damage.

88. Sun J, Zhang Y, Song X, Zhu J, Zhu Q. The healing effects of conditioned medium derived from mesenchymal stem cells on radiation-induced skin wounds in rats. Cell Transplant. 2019;28(1):105-15. https://doi.org/10.1177/0963689718807410 This study demonstrated that WJ-MSC-derived conditioned medium significantly accelerated wound closure and enhanced the wound healing quality. So, the WJ-MSC-CM may serve as a basis of a novel cell-free therapeutic approach for radiation dermatitis.

Publisher's Note Springer Nature remains neutral with regard to jurisdictional claims in published maps and institutional affiliations. 